\title{
Chemokine Receptor CXCR3 Measurement
}

National Cancer Institute

\section{Source}

National Cancer Institute. Chemokine Receptor CXCR3 Measurement. NCI Thesaurus. Code C100431.

The determination of the amount of chemokine receptor CXCR3 present in a sample. 